Article

\title{
Recovery of Alkali from Bayer Red Mud Using CaO and/or MgO
}

\author{
Bingxin Zhou ${ }^{1,2,3,4}$, Shaotao Cao ${ }^{2,3, *}$, Fangfang Chen ${ }^{2,3}$, Fangfang Zhang ${ }^{2,3}$ and Yi Zhang ${ }^{2,3}$ \\ 1 School of Chemical Engineering and Technology, Tianjin University, Tianjin 300072, China; \\ zhoubingxin@163.com \\ 2 Key Laboratory of Green Process and Engineering, Institute of Process Engineering, Chinese Academy of \\ Sciences, Beijing 100190, China; ffchen@ipe.ac.cn (F.C.); ffzhang@ipe.ac.cn (F.Z.); yizh@ipe.ac.cn (Y.Z.) \\ 3 National Engineering Laboratory for Hydrometallurgical Cleaner Production Technology, Institute of \\ Process Engineering, Chinese Academy of Sciences, Beijing 100190, China \\ 4 National Engineering Research Center of Distillation Technology, Tianjin 300072, China \\ * Correspondence: stcao@ipe.ac.cn; Tel.: +86-1082544884
}

Received: 29 March 2019; Accepted: 26 April 2019; Published: 30 April 2019

\begin{abstract}
Recovering alkali from Bayer red mud is crucial for storage security, resource utilization and environmental protection. In this study, the addition of $\mathrm{MgO}$ and/or $\mathrm{CaO}$ was conducted to recover alkali from red mud with a hydrothermal method for the first time. A synergistic result with a residual $\mathrm{Na}_{2} \mathrm{O} / \mathrm{SiO}_{2}$ weight ratio of 0.03 was obtained by adding the blend of $\mathrm{CaO}$ and $\mathrm{MgO}$ at an appropriate temperature. $\mathrm{MgO}$ was found to be more temperature-dependent than $\mathrm{CaO}$ when substituting $\mathrm{Na}_{2} \mathrm{O}$ from red mud due to their different hydration processes. The alkali recovery was controlled by a reaction at a temperature of $<200{ }^{\circ} \mathrm{C}$ and by internal diffusion at a higher temperature for $\mathrm{MgO}$, but controlled by internal diffusion for $\mathrm{CaO}$ in the whole temperature range studied. The formation of hydrotalcite-like compounds with a loose structure was verified with the help of XRD, FTIR, and SEM-EDS. It was proved that both the reaction kinetics and the characteristics of solid products have a significant influence on the recovery of alkali.
\end{abstract}

Keywords: recovering alkali; Bayer red mud; reaction kinetics; magnesium oxide; hydrotalcite-like compounds

\section{Introduction}

Red mud is the solid waste emitted from the aluminum industry. China produced 69.02 million tons of alumina in 2017, with more than 100 million tons of red mud generated [1]. The $\mathrm{pH}$ of red mud ranges from 9.2 to 13.0 with an average value of $11.3 \pm 1.0$, and the high alkalinity of red mud is the primary reason for its classification as a hazardous material [2-5]. Although most alumina producers dispose of this residue in tailing dams [6], this is in no way a long-term solution considering the associated security, environmental and utilization problems [7-10].

Several processes have been proposed to neutralize the alkali in red mud, such as acids and acid gases neutralization, seawater neutralization, microbial neutralization and revegetation $[4,8,11-15]$, among which seawater neutralization has been highly valued for the abundance and low cost of seawater. In the seawater neutralization process, the $\mathrm{Ca}$ - and $\mathrm{Mg}$-rich brines play an important role in the reduction of $\mathrm{pH}$ and in the precipitation of hydroxide, carbonate or hydroxycarbonate minerals $[13,16,17]$. However, this method is only suitable for coastal areas.

In addition, leaching and recovering alkali from red mud has also been widely investigated, such as the soda-lime roasting process, solvent extraction process, calcification-carbonation method, and water leaching and hydro-chemical process [8,18-20]. The addition of lime has been widely studied 
because of its excellent performance in replacing $\mathrm{Na}_{2} \mathrm{O}$, as well as its abundance and cheapness. In fact, the insoluble sodium mainly lies in cancrinite, and the sodium can be leached out from it only if the structure is broken down, or the included $\mathrm{Na}^{+}$can be removed through the opening of the cancrinite structure. Therefore, the leaching process is based on the ion exchange between $\mathrm{Ca}^{2+}$ and $\mathrm{Na}^{+}[4]$. There are many studies about leaching alkali from red mud with lime, including the industrial use of lime to remove alkali, such as the "Lime Bayer" process and the Sagin process [4]. Yang et al. and Luo et al. investigated the recovery ratio of alkali with the addition of lime under different conditions, and obtained the best recovery ratio of $80 \%$ [21,22]. Li et al. conducted a thermodynamic analysis of the calcification reaction and studied the calcification mechanism under different conditions focusing on the calcification-carbonation processes [23].

To summarize, $\mathrm{CaO}$ or $\mathrm{MgO}$ plays an essential part in alkali recovery and $\mathrm{pH}$ reduction of red mud because of its high efficiency, low cost and absence of secondary pollution, unlike Ca- and $\mathrm{Mg}$-rich brines. However, few examples from the literature have systematically reported the differences in using $\mathrm{CaO}$ and/or $\mathrm{MgO}$ as additions to recover alkali from red mud. Venancio et al. added $\mathrm{CaO} / \mathrm{MgO}$ before the carbonation, but only reported the change of $\mathrm{pH}$ [24].

In this study, the hydrothermal reaction using a different molar ratio of $\mathrm{CaO} / \mathrm{MgO}$ blend to recover alkali was conducted at different temperatures to determine the alkali recovery capacity, and the best recovery efficiency reached $89.3 \%$ with a residual $\mathrm{Na}_{2} \mathrm{O} / \mathrm{SiO}_{2}$ weight ratio (N/S) of 0.03 . The reaction kinetics was regressed to ascertain the rate controlling step. Moreover, the detection of phase composition, infrared spectroscopy analysis and micro-zone analysis were used to study the differences in $\mathrm{CaO} / \mathrm{MgO}$ dealkalization. This study can provide reference for the reaction mechanism investigations of alkali recovery from red mud based on ion exchange.

\section{Materials and Methods}

\subsection{Materials}

Calcium oxide ( $\mathrm{CaO}, \mathrm{AR})$ and magnesium oxide $(\mathrm{MgO}, \mathrm{AR})$ were purchased from Beijing Chemical Industry Co. Ltd. and were used as received. Deionized water was used in all experiments. Red mud was supplied by Coalmine Alumina Co., Henan Province, China, dried overnight at $105^{\circ} \mathrm{C}$ on the ground, and finally put through a 200-mesh sieve. The standard reference red mud was from Zhengzhou Light Metals Research Institute of CHINALCO, Henan Province, China. The flux $\left(\mathrm{Li}_{2} \mathrm{~B}_{4} \mathrm{O}_{7}: \mathrm{LiBO}_{2}=12: 22\right)$ was purchased from Luoyang Tenai Laboratory Equipment Co., Ltd., Henan Province, China.

\subsection{Experimental Methods}

The experiments were carried out in $150 \mathrm{~mL}$ steel bomb reactors which were placed in a homogeneous bath furnace. The reactors were made of nickel metal, and the furnace was filled with glycerin when the temperature was $\leq 160{ }^{\circ} \mathrm{C}$, while filled with a molten salt of 53 wt. \% of $\mathrm{KNO}_{3}$, 40 wt. $\%$ of $\mathrm{NaNO}_{2}$, and 7 wt. \% of $\mathrm{NaNO}_{3}$ when the temperature was higher than $160{ }^{\circ} \mathrm{C}$. The agitation of the reaction was driven by the rotation of the steel bombs at a speed of $30 \mathrm{rpm}$ and strengthened by the addition of nickel beads. The temperature of the furnace was controlled within $\pm 0.5^{\circ} \mathrm{C}$.

For each experiment, $15 \mathrm{~g}$ red mud and a blend with a specific molar ratio of $\mathrm{CaO}$ to $\mathrm{MgO}$ (100\%:0\%, 90\%:10\%, 70\%:30\%, 50\%:50\%, 30\%:70\%, 10\%:90\% and 0\%:100\%) was added in each steel bomb reactor. The liquid to solid (L/S) weight ratio was fixed at $4: 1$, which was the same as in the latest literature focusing on alkali recovery of red mud [23]. The total amount of $\mathrm{CaO}$ and $\mathrm{MgO}$ in each bomb reactor was $0.056 \mathrm{~mol}$ and remained constant, with the $\mathrm{CaO}$ and/or $\mathrm{MgO}: \mathrm{Na}_{2} \mathrm{O}$ molar ratio remaining at $4: 1[23,25]$. The steel bomb reactors were then put in the furnace. The furnace was heated to $20^{\circ} \mathrm{C}$ below the scheduled temperature in advance, and the start of the reaction was recorded upon reaching the experimental temperature. The steel bombs were removed after reaction for $3 \mathrm{~h}$, and then quickly 
cooled in water. The solid cake and the filtrate were obtained by filtration. The obtained solids were washed by deionized water and dried in a laboratory oven at $105^{\circ} \mathrm{C}$ for subsequent analysis.

\subsection{Analytical Methods}

The content of water-soluble sodium in the red mud was obtained by the titration method of the Pingguo alumina factory, Guangxi, CHALCO. The analysis process is shown as follows:

(a) An amount of $5 \mathrm{~g}$ red mud and $200 \mathrm{~mL}$ sodium chloride solution $(0.1000 \mathrm{~mol} / \mathrm{L})$ were added in a $500 \mathrm{~mL}$ conical flask, and then the suspension was agitated for $15 \mathrm{~min}$ by a magnetic stirrer at an agitation speed of $300 \mathrm{rpm}$, before being filtrated.

(b) An amount of $100 \mathrm{~mL}$ liquid filtrate obtained by filtration was moved into a $250 \mathrm{~mL}$ conical flask, and the liquid was concentrated to about $50 \mathrm{~mL}$, and heated in an electric furnace.

(c) Between six and eight drops of bromothymol blue were added into the concentrated liquid and then the liquid was rapidly titrated with hydrochloric acid $(0.1000 \mathrm{~mol} / \mathrm{L})$. We stopped adding hydrochloric acid when the color changed from blue to yellow and recorded the volume $(V, \mathrm{~mL})$ of the hydrochloric acid used.

The content of water-soluble sodium in the red mud could be calculated through Equation (1):

$$
\mathrm{Na}_{2} \mathrm{O} \text { wt. } \%=0.1 \times \frac{V}{1000} \times \frac{200}{100} \times \frac{62}{2} \times \frac{100}{5}=0.124 \times V
$$

The chemical composition of the solids was determined by X-ray Fluorescence (XRF, ARL9800XP, Thermofisher, Waltham, MA, USA). The loss of sodium from the red mud could be obtained by the XRF measurement and calculation. The samples were pressed into disks before measurement: (1) the solid samples were finely ground and dried at $110^{\circ} \mathrm{C}$ for $1 \mathrm{~h}$; (2) $0.7000 \mathrm{~g}$ sample and $5.6000 \mathrm{~g}$ flux were mixed and melted into a disk with an automatic melting furnace (FLUXY10, Classise, Mississauga, Ontario, Canada). The disks were subsequently analyzed using the XRF instrument, operated at $30 \mathrm{kV}$ and $80 \mathrm{~mA}$. The elemental concentrations $\left(\mathrm{Al}_{2} \mathrm{O}_{3}, \mathrm{Fe}_{2} \mathrm{O}_{3}, \mathrm{CaO}, \mathrm{TiO}_{2}, \mathrm{SiO}_{2}, \mathrm{MgO}, \mathrm{Na}_{2} \mathrm{O}\right.$ and $\mathrm{K}_{2} \mathrm{O}$ ) were quantified based on the measurements of disks using the MVR software. Prior to the analysis of the samples, the XRF instrument was calibrated with standard reference red mud and the intensity-concentration working curve was made.

During the hydrothermal process, the silicon oxide would not be leached into the liquor, and the recovery ratio of alkali from the red mud could be calculated through Equation (2):

$$
\alpha=\left(1-\frac{N}{N_{0}}\right) \times 100 \%
$$

where $\alpha$ was the recovery ratio of alkali, $N$ was the N/S in the solid sample, and $N_{0}$ was the N/S of the initial red mud.

X-ray diffraction patterns of the solids were identified from powder diffraction patterns (XRD, $X^{\prime}$ pert MPD Pro, PanAnalytical, Almelo, the Netherlands) recorded with $\mathrm{Cu} K_{\alpha}(\lambda=0.15408 \mathrm{~nm})$ radiation. The structural investigation of solids was carried out by Fourier transform infrared spectroscopy (FTIR, T27-Hyperion-Vector22, Bruker, Bremen, Germany). The surface morphology of samples was detected by scanning electron microscopy (SEM, JSM-7001F, JEOL, Tokyo, Japan) with energy dispersive X-ray spectroscopy (EDS, Inca X-MAX, Oxford, UK).

\section{Results and Discussion}

\subsection{Characterization of Bayer Red Mud}

From the $\mathrm{X}$-ray diffraction patterns in Figure 1, Bayer red mud mainly consists of cancrinite $\left(\mathrm{Na}_{8}\left(\mathrm{Si}_{6} \mathrm{Al}_{6} \mathrm{O}_{24}\right)\left(\mathrm{H}_{0.88}\left(\mathrm{CO}_{3}\right)_{1.44}\right)\left(\mathrm{H}_{2} \mathrm{O}\right)_{2}\right)$, katoite $\left(\mathrm{Ca}_{2.93} \mathrm{Al}_{1.97} \mathrm{Si}_{0.64} \mathrm{O}_{2.56}(\mathrm{OH})_{9.44}\right)$, hematite $\left(\mathrm{Fe}_{2} \mathrm{O}_{3}\right)$, perovskite $\left(\mathrm{CaTiO}_{3}\right)$ and calcite $\left(\mathrm{CaCO}_{3}\right)$. The main chemical composition of red mud is shown in Table 1 and $\mathrm{Na}_{2} \mathrm{O}$ accounts for 5.97 wt. \% in the red mud. The content of water-soluble sodium in 
the red mud was obtained with the titration method as shown in Section 2.3, and the result showed that $V$ equaled $0.95 \mathrm{~mL}$, so the water-soluble sodium and water-insoluble sodium were calculated for $2.0 \mathrm{wt}$ \% $\%$ and $98.0 \mathrm{wt}$. \% of the total sodium in the red mud, respectively. Besides, the X-ray diffraction pattern in Figure 1 shows no detectable changes after the removal of water-soluble sodium. It is thus inferred that most water-insoluble alkaline lies in the cancrinite. In Figure 2, it can be seen that the particles of the red mud show irregular appearance and the distribution of sodium atoms focuses on some specific particles, which is consistent with the previous assertion that most of the alkali lies in cancrinite.

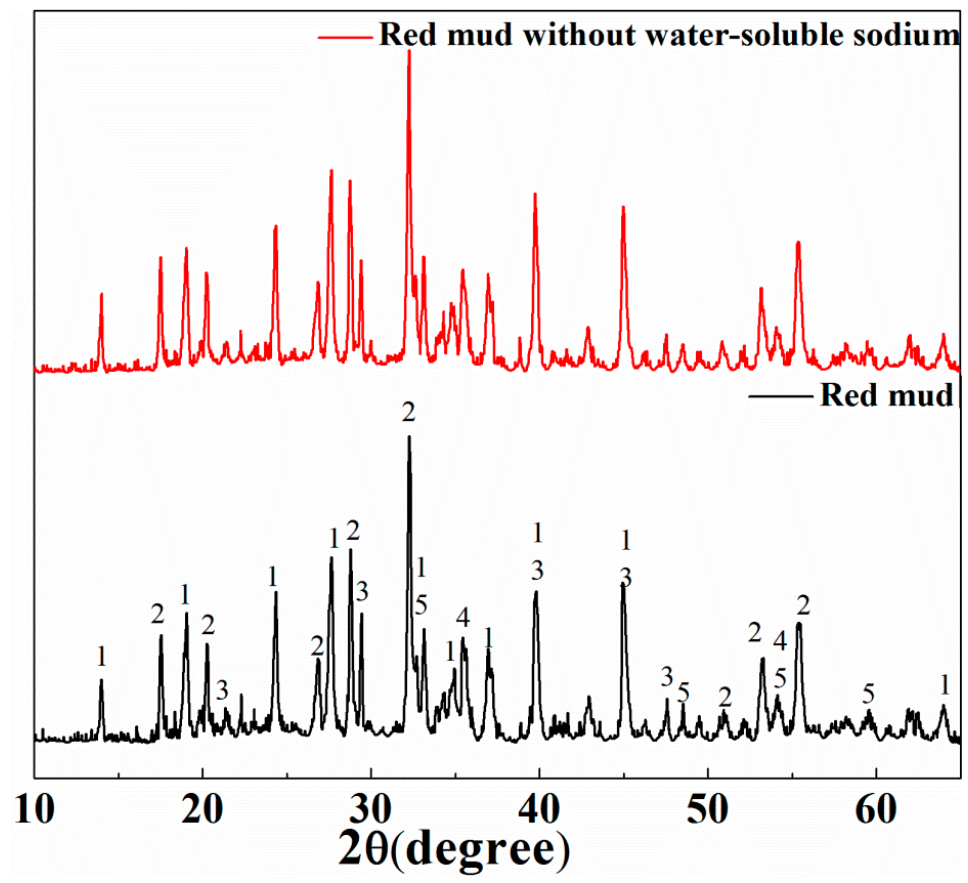

Figure 1. X-ray diffraction analysis of Bayer red mud $\left(1-\mathrm{Na}_{8} \mathrm{Si}_{6} \mathrm{Al}_{6} \mathrm{O}_{24}\left(\mathrm{H}_{0.88}\left(\mathrm{CO}_{3}\right)_{1.44}\right)\left(\mathrm{H}_{2} \mathrm{O}\right)_{2}\right.$; $\left.2-\mathrm{Ca}_{2.93} \mathrm{Al}_{1.97} \mathrm{Si}_{0.64} \mathrm{O}_{2.56}(\mathrm{OH})_{9.44} ; 3-\mathrm{CaCO}_{3} ; 4-\mathrm{Fe}_{2} \mathrm{O}_{3} ; 5-\mathrm{CaTiO}_{3}\right)$.
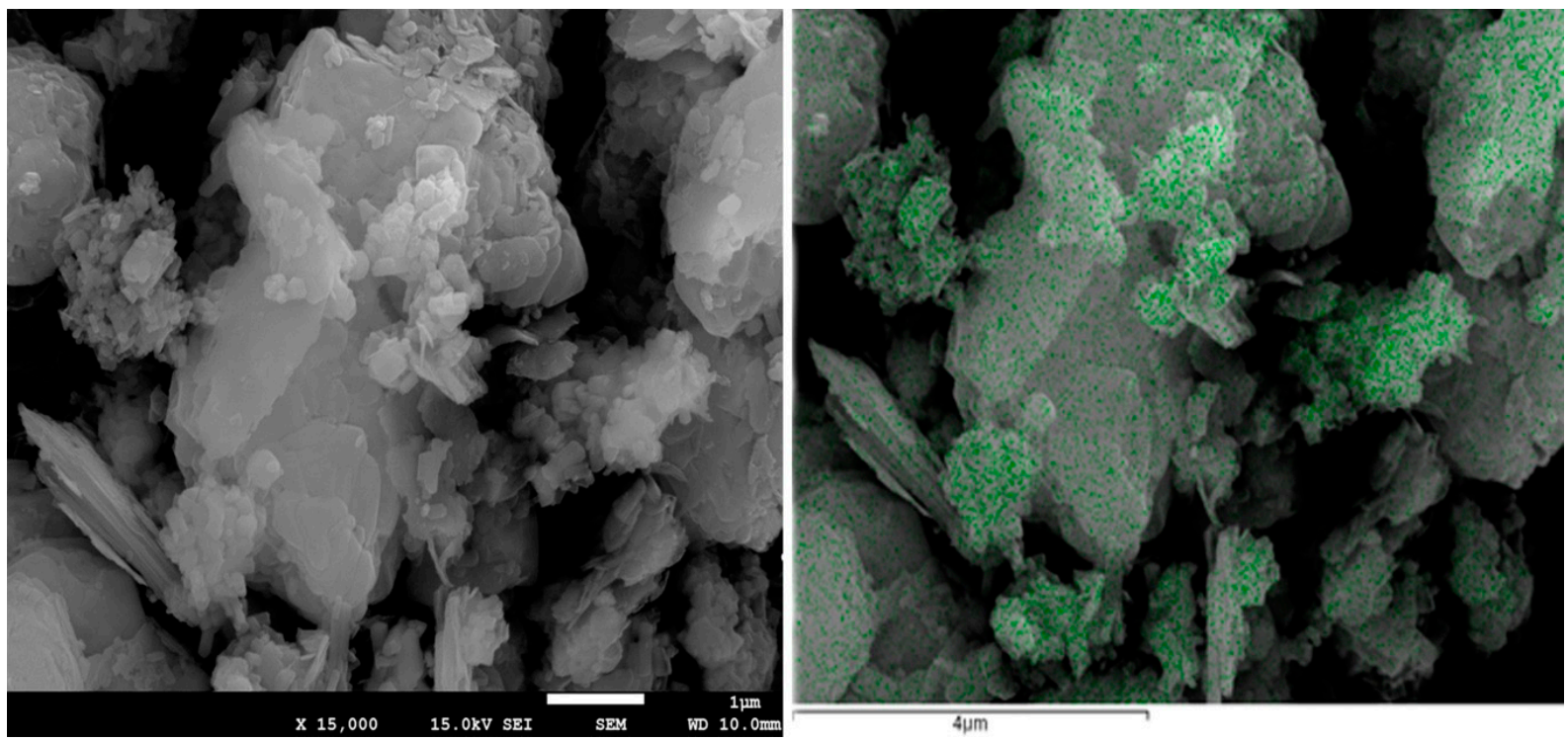

Figure 2. Morphology of the red mud (the green parts represent $\mathrm{Na}$ ). 
Table 1. Main chemical composition of Bayer red mud measured by X-ray fluorescence.

\begin{tabular}{cccccccccc}
\hline Chemicals & $\mathrm{Al}_{2} \mathrm{O}_{3}$ & $\mathrm{SiO}_{2}$ & $\mathrm{CaO}$ & $\mathrm{Fe}_{2} \mathrm{O}_{3}$ & $\mathrm{Na}_{2} \mathrm{O}$ & $\mathrm{TiO}_{2}$ & $\mathrm{~K}_{2} \mathrm{O}$ & $\mathrm{MgO}$ & $\mathrm{N} / \mathrm{S}$ \\
\hline Content (wt. \%) & 24.42 & 21.12 & 18.47 & 8.14 & 5.97 & 4.56 & 1.53 & 0.75 & 0.28 \\
\hline
\end{tabular}

\subsection{Recovery of $\mathrm{Na}_{2} \mathrm{O}$ Using $\mathrm{CaO} / \mathrm{MgO}$}

The influence of temperature on alkali recovery efficiency was investigated. The results are illustrated in Figure 3 with pure $\mathrm{CaO}$ or $\mathrm{MgO}$ as an addition, and it is found that the recovery ratio of $\mathrm{Na}_{2} \mathrm{O}$ positively correlates with temperature. The recovery ratio increased smoothly from $72.5 \%$ to $80.9 \%$ in the temperature range of $90-210^{\circ} \mathrm{C}$ with $\mathrm{CaO}$ as an addition, but more sharply from $13.4 \%$ to $78.9 \%$ when $\mathrm{MgO}$ was added from $90^{\circ} \mathrm{C}$ to $200{ }^{\circ} \mathrm{C}$, and then only improved to $79.9 \%$ when the temperature further increased to $210^{\circ} \mathrm{C}$. Although the recovery efficiencies of $\mathrm{Na}_{2} \mathrm{O}$ with $\mathrm{CaO}$ as an addition were always higher than those with $\mathrm{MgO}$, the relative efficiency $(\mathrm{MgO}: \mathrm{CaO})$ increased from $18.5 \%$ to $98.8 \%$ when temperature increased from $90^{\circ} \mathrm{C}$ to $210^{\circ} \mathrm{C}$. Moreover, the recovery efficiency was similar for both $\mathrm{CaO}$ and $\mathrm{MgO}$ at temperatures $\geq 200^{\circ} \mathrm{C}$.

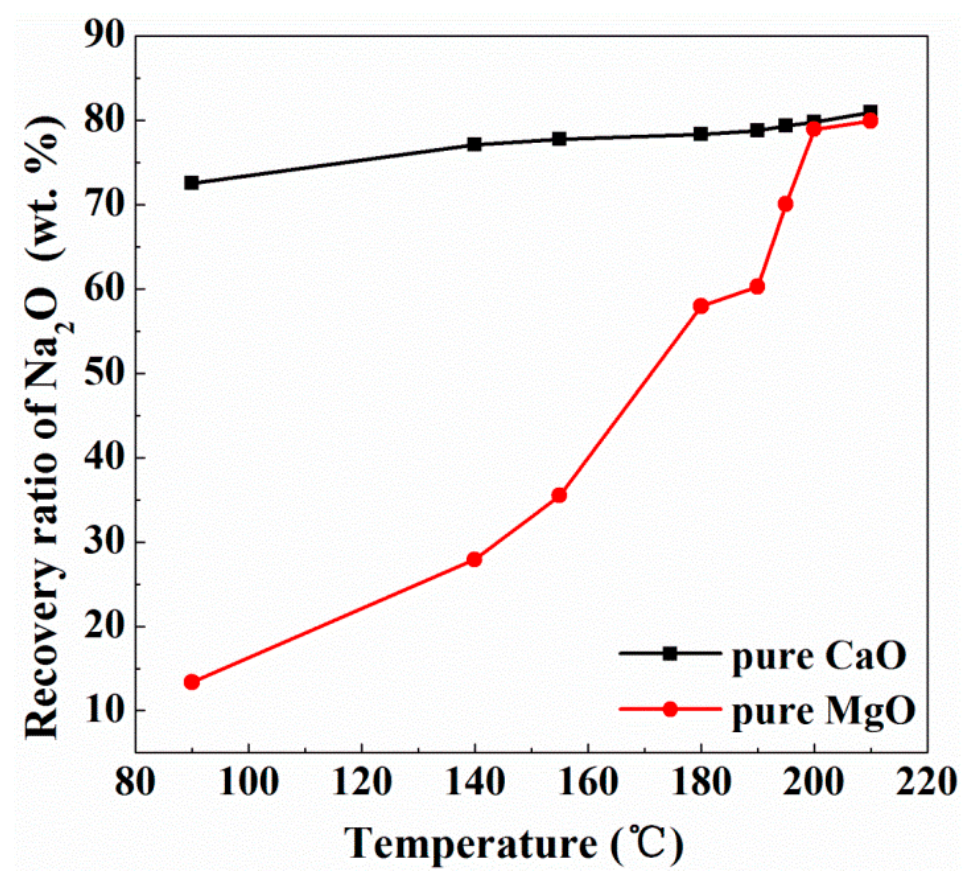

Figure 3. Influence of temperature on the recovery ratio of $\mathrm{Na}_{2} \mathrm{O}$ using pure $\mathrm{CaO} / \mathrm{MgO}(t=3 \mathrm{~h})$.

Nevertheless, the recovery of sodium oxide shows a totally different rule with the blend of $\mathrm{CaO}$ and $\mathrm{MgO}$ as an addition, as shown in Figure 4. For instance, the recovery efficiency decreased with the increasing proportion of $\mathrm{MgO}$ when the temperature was lower than $200^{\circ} \mathrm{C}$. However, the recovery ratios of $\mathrm{Na}_{2} \mathrm{O}$ with $10 \%$ to $50 \%$ (molar ratio) $\mathrm{MgO}$ addition were higher than those of the single use of $\mathrm{CaO}$ or $\mathrm{MgO}$ when the temperature was higher than $200^{\circ} \mathrm{C}$, and the maximum was obtained at $50 \%$ $\mathrm{MgO}$ addition. The best recovery of $\mathrm{Na}_{2} \mathrm{O}$ was $89.3 \%$ in the experimental range, with $\mathrm{N} / \mathrm{S}$ of 0.03 and only $0.64 \mathrm{wt}$. $\% \mathrm{Na}_{2} \mathrm{O}$ left in the residue. 


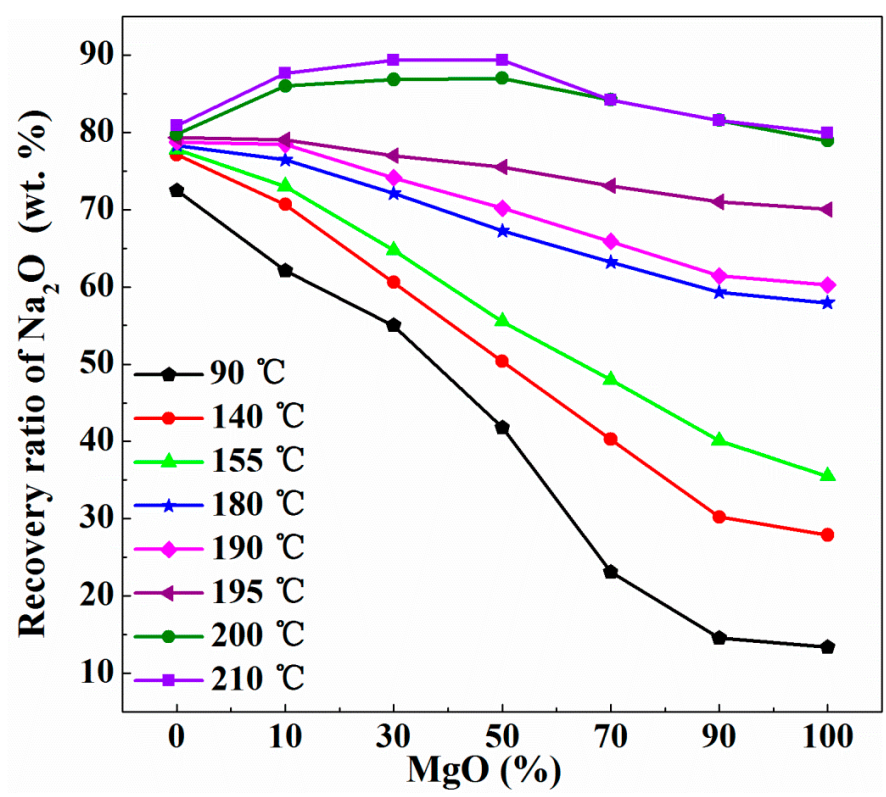

Figure 4. Influence of blending $\mathrm{MgO}$ and $\mathrm{CaO}$ on the recovery ratio of $\mathrm{Na}_{2} \mathrm{O}(t=3 \mathrm{~h}, \%$ means the mole fraction of $\mathrm{MgO}$ addition).

\subsection{Phase Differences of $\mathrm{CaO} / \mathrm{MgO}$ Substituting $\mathrm{Na}_{2} \mathrm{O}$}

As shown in Figure 5a, the dealkalization product bearing $\mathrm{Ca}$ is attributed to katoite with $\mathrm{CaO}$ as an addition [23]. However, as shown in Figure 5b,c, most residues bearing $\mathrm{Mg}$ are $\mathrm{MgO}$ and $\mathrm{Mg}(\mathrm{OH})_{2}$ with $\mathrm{MgO}$ as an addition at a temperature lower than $200^{\circ} \mathrm{C}$, indicating the incomplete hydration of $\mathrm{MgO}$ and the difficulty in leaching $\mathrm{Na}_{2} \mathrm{O}$. In fact, temperature has been proven to play an important role in the hydration process of $\mathrm{MgO}[26,27]$. As the alkali recovery was based on the ion exchange between $\mathrm{Ca}^{2+} / \mathrm{Mg}^{2+}$ and $\mathrm{Na}^{+}$[23], the hydration of $\mathrm{MgO}$ and $\mathrm{CaO}$ to dissociate the ion was of great importance to the alkali recovery. The reaction kinetics will be discussed in Section 3.4. The XRD patterns in Figure 5 and Table 2 also show the appearance of $\left(\mathrm{Mg}_{4.5} \mathrm{Al}_{1.5}\right)\left(\mathrm{Si}_{2.5} \mathrm{Al}_{1.5}\right) \mathrm{O}_{10}(\mathrm{OH})_{8}$ which is a kind of hydrotalcite-like compound and contributed to the sodium removal. The related reactions can be simplified as follows:

$$
\begin{gathered}
\mathrm{Na}_{8}\left(\mathrm{Si}_{6} \mathrm{Al}_{6} \mathrm{O}_{24}\right)\left(\mathrm{H}_{0.88}\left(\mathrm{CO}_{3}\right)_{1.44}\right)\left(\mathrm{H}_{2} \mathrm{O}\right)_{2}+\mathrm{CaO}+\mathrm{H}_{2} \mathrm{O} \rightarrow \mathrm{Ca}_{2.93} \mathrm{Al}_{1.97} \mathrm{Si}_{0.64} \mathrm{O}_{2.56}(\mathrm{OH})_{9.44}+ \\
\mathrm{CaCO}_{3}+\mathrm{Na}^{+}+\mathrm{OH}^{-} \\
\mathrm{Na}_{8}\left(\mathrm{Si}_{6} \mathrm{Al}_{6} \mathrm{O}_{24}\right)\left(\mathrm{H}_{0.88}\left(\mathrm{CO}_{3}\right)_{1.44}\right)\left(\mathrm{H}_{2} \mathrm{O}\right)_{2}+\mathrm{MgO}+\mathrm{H}_{2} \mathrm{O} \rightarrow\left(\mathrm{Mg}_{4.5} \mathrm{Al}_{1.5}\right)\left(\mathrm{Si}_{2.5} \mathrm{Al}_{1.5}\right) \mathrm{O}_{10}(\mathrm{OH})_{8}+ \\
\mathrm{CO}_{3}{ }^{2-}+\mathrm{Na}^{+}+\mathrm{OH}^{-}
\end{gathered}
$$

Table 2. XRD patterns of solid products at temperatures $<200{ }^{\circ} \mathrm{C}$.

\begin{tabular}{ccccc}
\hline $\mathbf{M g O} \%$ & Temperature $^{\circ} \mathbf{C}$ & $\mathbf{M g O}$ & $\mathbf{M g}(\mathbf{O H})_{2}$ & $\left(\mathbf{M g}_{4.5} \mathbf{A l}_{1.5}\right)\left(\mathbf{S i}_{2.5} \mathbf{A l}_{1.5}\right) \mathbf{O}_{10}(\mathbf{O H})_{8}$ \\
\hline \multirow{2}{*}{0} & 90 & $\mathrm{x}$ & $\mathrm{x}$ & $\mathrm{x}$ \\
& 140 & $\mathrm{x}$ & $\mathrm{x}$ & $\mathrm{x}$ \\
& 190 & $\mathrm{x}$ & $\mathrm{x}$ & $\mathrm{x}$ \\
\hline \multirow{2}{*}{50} & 90 & $\sqrt{ }$ & $\sqrt{ }$ & $\mathrm{x}$ \\
& 140 & $\sqrt{ }$ & $\sqrt{ }$ & $\mathrm{x}$ \\
& 190 & $\sqrt{ }$ & $\sqrt{ }$ & $\mathrm{x}$ \\
& 90 & $\sqrt{ }$ & $\sqrt{ }$ & $\sqrt{ }$ \\
& 140 & $\sqrt{ }$ & $\sqrt{ }$ & $\sqrt{ }$ \\
\hline
\end{tabular}

$\%$ means the mole fraction of $\mathrm{MgO}$ addition; only new phases in each sample are listed out; $\sqrt{ }$ : existence; $\mathrm{x}$ : nonexistence. 

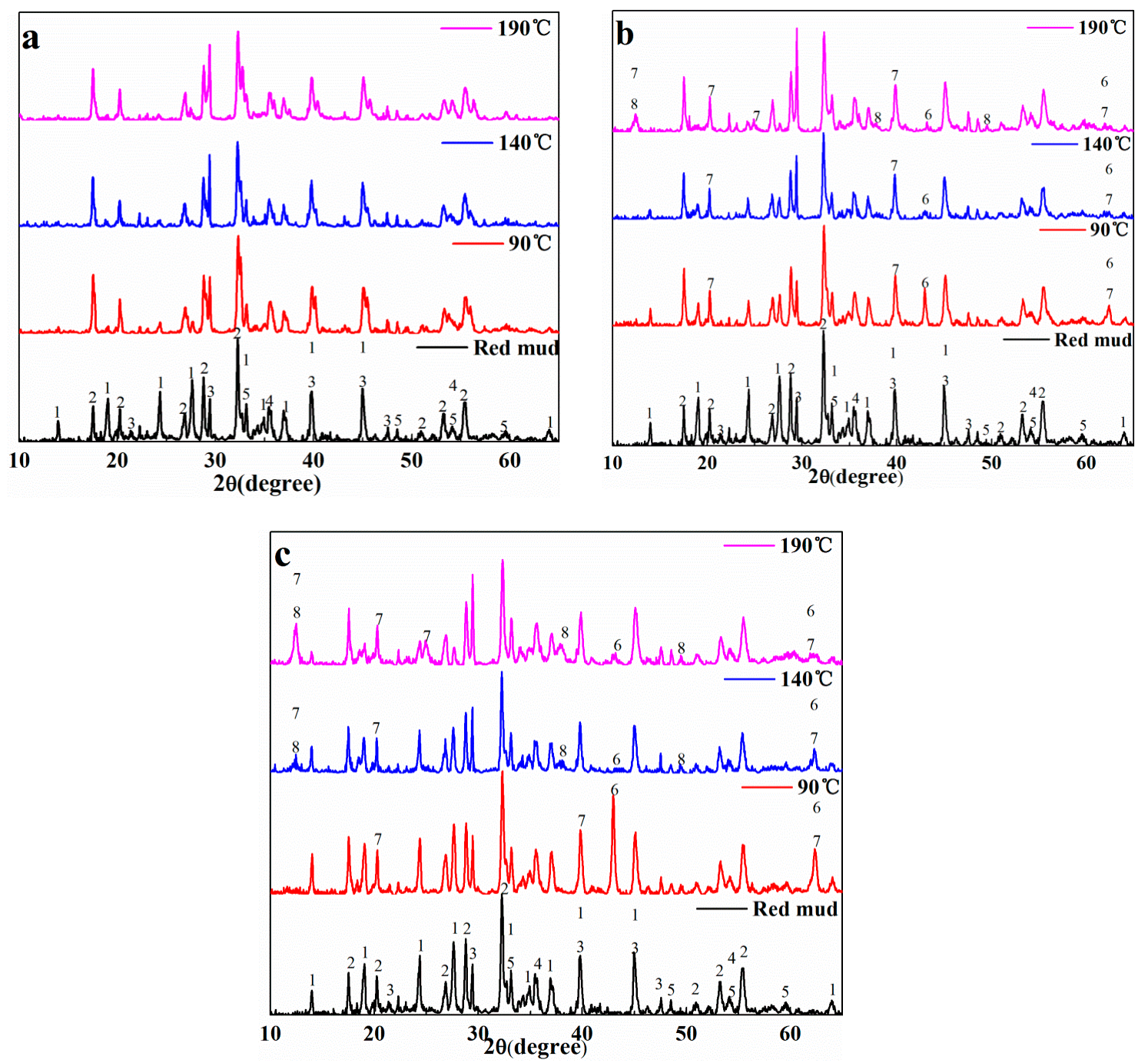

Figure 5. XRD patterns of solid products at temperatures $<200{ }^{\circ} \mathrm{C}$ : (a) $0 \% \mathrm{MgO}$ addition; (b) $50 \% \mathrm{MgO}$ addition; (c) $100 \% \mathrm{MgO}$ addition $\left(1-\mathrm{Na}_{8} \mathrm{Si}_{6} \mathrm{Al}_{6} \mathrm{O}_{24}\left(\mathrm{H}_{0.88}\left(\mathrm{CO}_{3}\right)_{1.44}\right)\left(\mathrm{H}_{2} \mathrm{O}\right)_{2}\right.$; 2- $\mathrm{Ca}_{2.93} \mathrm{Al}_{1.97} \mathrm{Si}_{0.64} \mathrm{O}_{2.56}(\mathrm{OH})_{9.44} ; 3-\mathrm{CaCO}_{3} ; 4-\mathrm{Fe}_{2} \mathrm{O}_{3} ;$ 5- $\mathrm{CaTiO}_{3} ; \quad 6-\mathrm{MgO} ; 7-\mathrm{Mg}(\mathrm{OH})_{2}$; $\left.8-\left(\mathrm{Mg}_{4.5} \mathrm{Al}_{1.5}\right)\left(\mathrm{Si}_{2.5} \mathrm{Al}_{1.5}\right) \mathrm{O}_{10}(\mathrm{OH})_{8}\right) ; \%$ means the mole fraction of $\mathrm{MgO}$ addition; only new phases are marked out while the same $\mathrm{XRD}$ pattern for the red mud is presented without labels in each figure for clarity).

When the temperature increases to $200{ }^{\circ} \mathrm{C}$, the changes in XRD patterns are shown in Figure 6 and Table 3. New hydrotalcite-like compounds of $\mathrm{Ca}_{10} \mathrm{Mg}_{2} \mathrm{Al}_{4}\left(\mathrm{SiO}_{4}\right)_{5}\left(\mathrm{Si}_{2} \mathrm{O}_{7}\right)_{2}(\mathrm{OH})_{4}$ and $\mathrm{Mg}_{3} \mathrm{Si}_{2} \mathrm{O}_{5}(\mathrm{OH})_{4}$ appear when $\mathrm{MgO}$ is added. The relating reactions can be simplified as follows:

$$
\begin{gathered}
\mathrm{Na}_{8}\left(\mathrm{Si}_{6} \mathrm{Al}_{6} \mathrm{O}_{24}\right)\left(\mathrm{H}_{0.88}\left(\mathrm{CO}_{3}\right)_{1.44}\right)\left(\mathrm{H}_{2} \mathrm{O}\right)_{2}+\mathrm{MgO}+\mathrm{H}_{2} \mathrm{O} \rightarrow \mathrm{Mg}_{3} \mathrm{Si}_{2} \mathrm{O}_{5}(\mathrm{OH})_{4}+ \\
\mathrm{Al}(\mathrm{OH})_{4}{ }^{+}+\mathrm{CO}_{3}{ }^{2-}+\mathrm{Na}^{+}+\mathrm{OH}^{-} \\
\mathrm{Na}_{8}\left(\mathrm{Si}_{6} \mathrm{Al}_{6} \mathrm{O}_{24}\left(\mathrm{H}_{0.88}\left(\mathrm{CO}_{3}\right)_{1.44}\right)\left(\mathrm{H}_{2} \mathrm{O}\right)_{2}+\mathrm{MgO}+\mathrm{CaO}+\mathrm{H}_{2} \mathrm{O} \rightarrow\right. \\
\mathrm{Ca}_{10} \mathrm{Mg}_{2} \mathrm{Al}_{4}\left(\mathrm{SiO}_{4}\right)_{5}\left(\mathrm{Si}_{2} \mathrm{O}_{7}\right)_{2}(\mathrm{OH})_{4}+\mathrm{Na}^{+}+\mathrm{CO}_{3}{ }^{2-}+\mathrm{OH}^{-}
\end{gathered}
$$



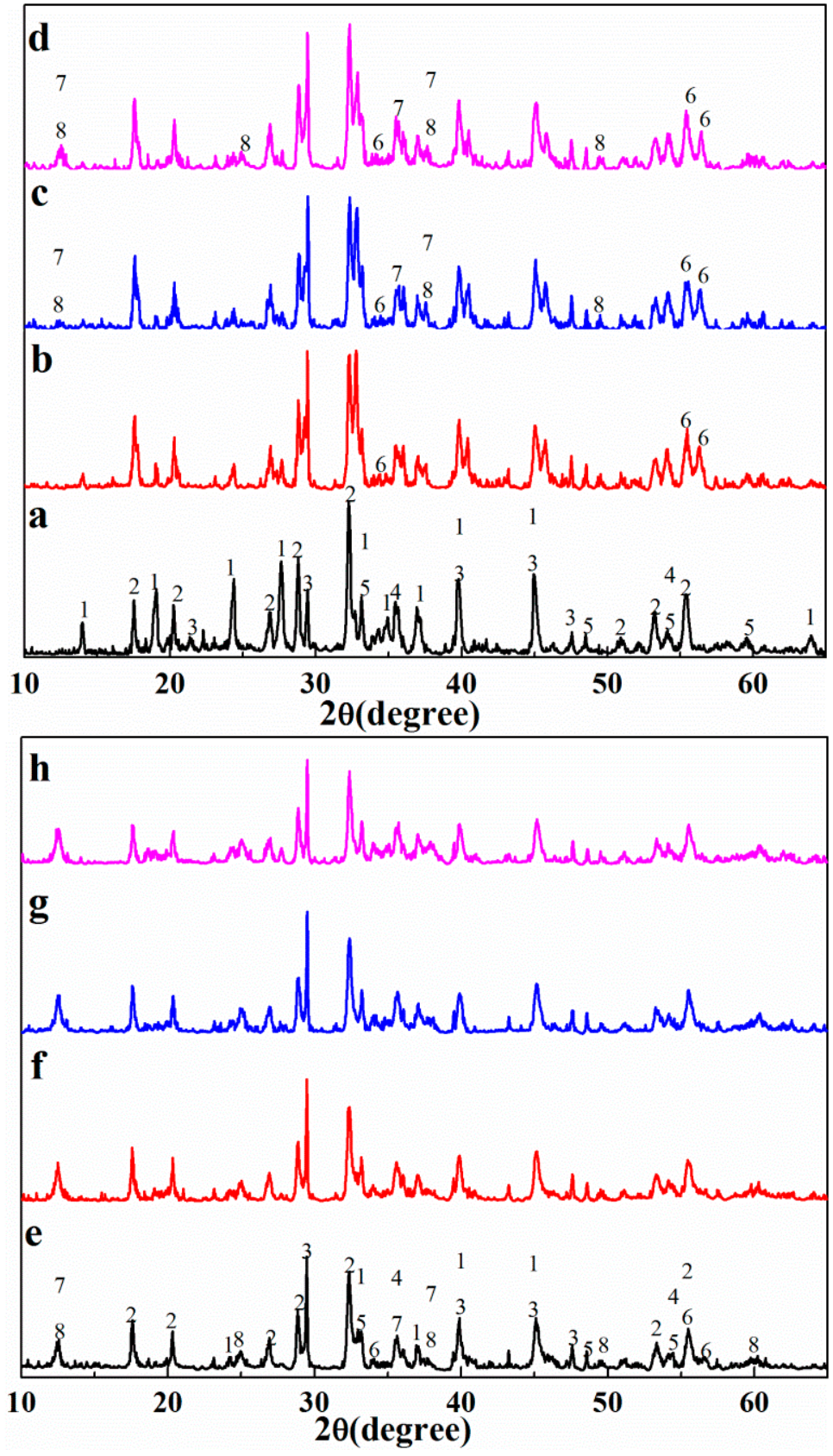

Figure 6. $\mathrm{XRD}$ patterns of the solid products at $200{ }^{\circ} \mathrm{C}$ : (a) Bayer red mud; (b) $0 \% \mathrm{MgO}$ addition; (c) $10 \% \mathrm{MgO}$ addition; (d) $30 \% \mathrm{MgO}$ addition; (e) $50 \%$ $\mathrm{MgO}$ addition; (f) $70 \% \mathrm{MgO}$ addition; (g) $90 \% \mathrm{MgO}$ addition and (h) $100 \% \mathrm{MgO}$ addition $\quad\left(1-\mathrm{Na}_{8} \mathrm{Si}_{6} \mathrm{Al}_{6} \mathrm{O}_{24}\left(\mathrm{H}_{0.88}\left(\mathrm{CO}_{3}\right)_{1.44}\right)\left(\mathrm{H}_{2} \mathrm{O}\right)_{2} ; \quad\right.$ 2- $\mathrm{Ca}_{2.93} \mathrm{Al}_{1.97} \mathrm{Si}_{0.64} \mathrm{O}_{2.56}(\mathrm{OH})_{9.44}$; $3-\mathrm{CaCO}_{3} ; 4-\mathrm{Fe}_{2} \mathrm{O}_{3} ; \quad 5-\mathrm{CaTiO}_{3} ; 6-\mathrm{Ca}_{10} \mathrm{Mg}_{2} \mathrm{Al}_{4}\left(\mathrm{SiO}_{4}\right)_{5}\left(\mathrm{Si}_{2} \mathrm{O}_{7}\right)_{2}(\mathrm{OH})_{4} ; 7-\mathrm{Mg}_{3} \mathrm{Si}_{2} \mathrm{O}_{5}(\mathrm{OH})_{4}$; $\left.8-\left(\mathrm{Mg}_{4.5} \mathrm{Al}_{1.5}\right)\left(\mathrm{Si}_{2.5} \mathrm{Al}_{1.5}\right) \mathrm{O}_{10}(\mathrm{OH})_{8}\right) ; \%$ means the mole fraction of $\mathrm{MgO}$ addition; only new phases are marked out while the same XRD pattern for the red mud is presented without labels in each figure for clarity). 
Table 3. XRD patterns of the solid products at $200^{\circ} \mathrm{C}$.

\begin{tabular}{cccc}
\hline $\mathrm{MgO} \%$ & $\mathrm{Ca}_{10} \mathrm{Mg}_{2} \mathrm{Al}_{4}\left(\mathrm{SiO}_{4}\right)_{5}\left(\mathrm{Si}_{2} \mathrm{O}_{7}\right)_{2}(\mathrm{OH})_{4}$ & $\mathrm{Mg}_{3} \mathrm{Si}_{2} \mathrm{O}_{5}(\mathrm{OH})_{4}$ & $\left(\mathrm{Mg}_{4.5} \mathrm{Al}_{1.5}\right)\left(\mathrm{Si}_{2.5} \mathrm{Al}_{1.5}\right) \mathrm{O}_{10}(\mathrm{OH})_{8}$ \\
\hline 0 & $\mathrm{x}$ & $\mathrm{x}$ & $\mathrm{x}$ \\
10 & $\sqrt{ }$ & $\mathrm{x}$ & $\mathrm{V}$ \\
30 & $\sqrt{ }$ & $\sqrt{ }$ & $\sqrt{ }$ \\
50 & $\sqrt{ }$ & $\sqrt{ }$ & $\sqrt{ }$ \\
70 & $\sqrt{ }$ & $\sqrt{ }$ & $\sqrt{ }$ \\
90 & $\sqrt{ }$ & $\sqrt{ }$ & $\sqrt{ }$ \\
100 & $\sqrt{ }$ & $\mathrm{V}$ & \\
\hline
\end{tabular}

$\%$ means the mole fraction of $\mathrm{MgO}$ addition; only new phases in each sample are listed out; $\sqrt{ }$ : existence; $\mathrm{x}$ : nonexistence.

\subsection{Reaction Kinetics of Alkali Recovery}

The reaction kinetics has been implemented to express the alkali recovery process with $\mathrm{CaO}$ or $\mathrm{MgO}$ as an addition. According to the shrinking core model (SCM) $[28,29]$, the kinetic equation of the heterogeneous reaction can be expressed as Equation (7) if the process is controlled by internal diffusion or as Equation (8) if controlled by chemical reaction:

$$
\begin{gathered}
k_{\mathrm{a}} t=1-\frac{2}{3} \alpha-(1-\alpha)^{2 / 3} \\
k_{\mathrm{b}} t=1-(1-\alpha)^{1 / 3}
\end{gathered}
$$

where $t$ represents the reaction time (min), $\alpha$ is the recovery ratio of $\mathrm{Na}_{2} \mathrm{O}(\%), k_{\mathrm{a}}$ is the rate constant for the process of internal diffusion, and $k_{\mathrm{b}}$ is the rate constant for the chemical reaction. The external diffusion was not considered because the reaction system was fully stirred.

As shown in Figure 7, a period of time of $30 \mathrm{~min}$ was used because the reaction was relatively fast. The alkali recovery process is controlled by internal diffusion with $\mathrm{CaO}$ as an addition and the activation energy is calculated to be $12.67 \mathrm{~kJ} / \mathrm{mol}$. In contrast, the recovery process with $\mathrm{MgO}$ as an addition is controlled by chemical reaction with an apparent activation energy of $40.99 \mathrm{~kJ} / \mathrm{mol}$ when the temperature is lower than $200{ }^{\circ} \mathrm{C}$, while this process is controlled by internal diffusion with an apparent activation energy of $18.04 \mathrm{~kJ} / \mathrm{mol}$ when the temperature is higher than $200^{\circ} \mathrm{C}$. The supporting information showed the recovery ratio of alkali versus time (Supplementary Materials Tables S1 and S2) and the calculation of the $\mathrm{CaO} / \mathrm{MgO}$ leaching reaction with the other SCM model (Figure S1) to show the differences.
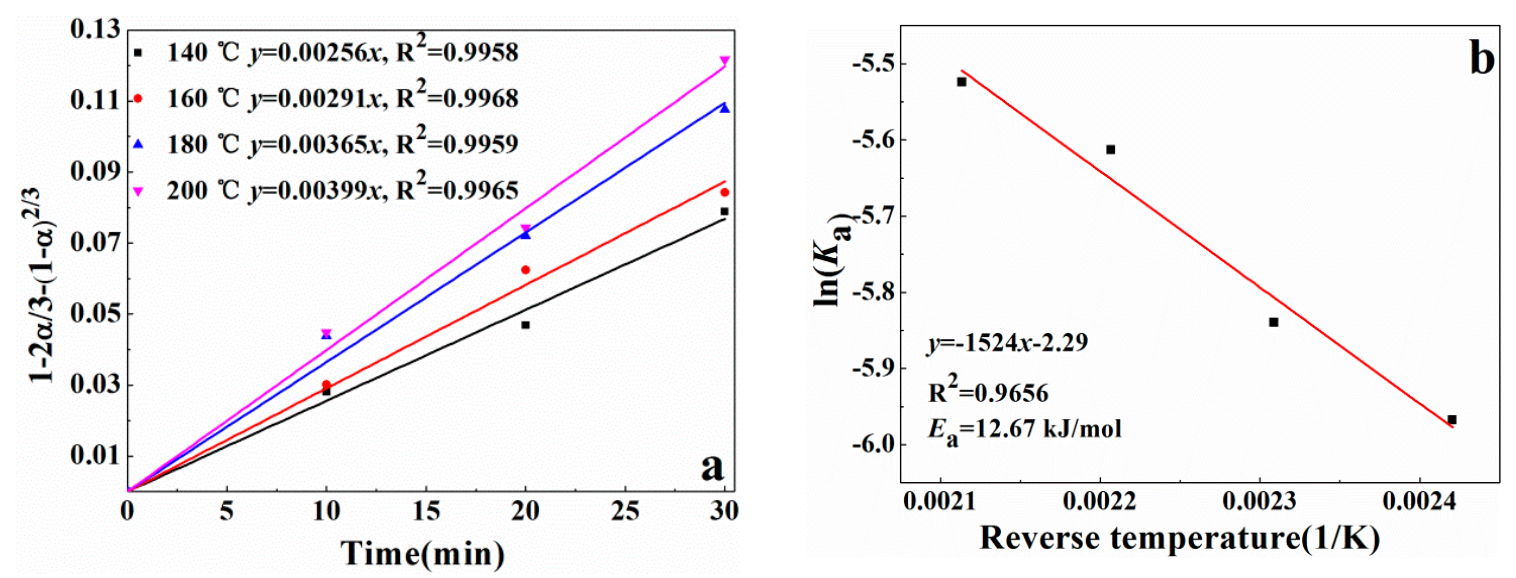

Figure 7. Cont. 

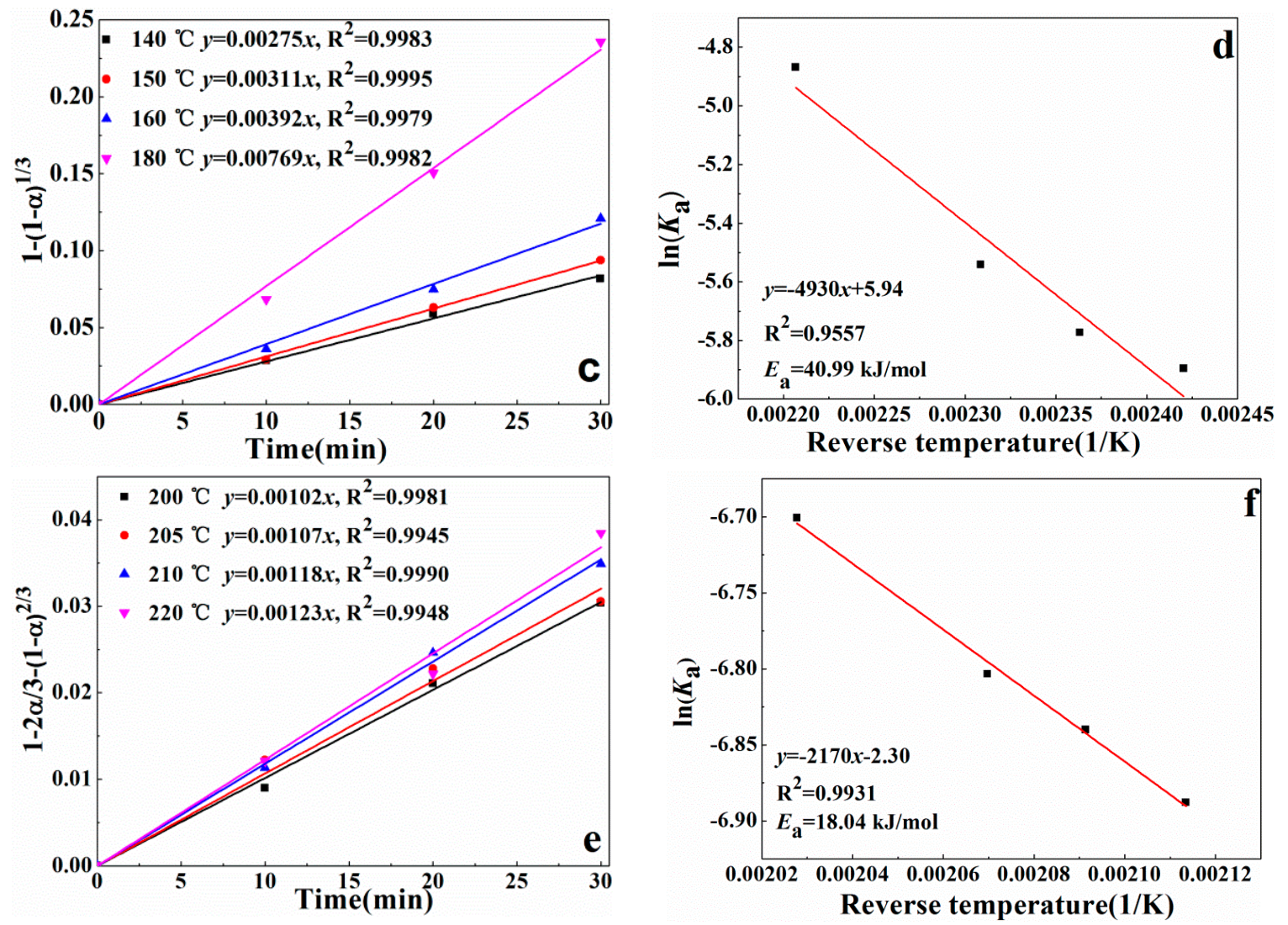

Figure 7. Kinetic fitting of (a) the plots of $\left[1-\frac{2}{3} \alpha(1-\alpha)^{2 / 3}\right]$ versus time for $\mathrm{CaO},(\mathbf{b}) \ln \left(K_{\mathrm{a}}\right)$ versus temperature for $\mathrm{CaO},(\mathbf{c})$ the plots of $\left[1-(1-\alpha)^{1 / 3}\right]$ versus time for $\mathrm{MgO}$ lower than $200{ }^{\circ} \mathrm{C},(\mathrm{d}) \ln \left(K_{\mathrm{a}}\right)$ versus temperature for $\mathrm{MgO}$ lower than $200{ }^{\circ} \mathrm{C}$, (e) the plots of $\left[1-\frac{2}{3} \alpha-(1-\alpha)^{2 / 3}\right]$ versus time for $\mathrm{MgO}$ higher than $200{ }^{\circ} \mathrm{C}$ and (f) $\ln (\mathrm{Ka})$ versus temperature for $\mathrm{MgO}$ higher than $200^{\circ} \mathrm{C}$.

The alkali recovery process can be principally divided into the following five steps: (1) the hydration of $\mathrm{CaO} / \mathrm{MgO}$; (2) the dissociation of $\mathrm{Ca}(\mathrm{OH})_{2} / \mathrm{Mg}(\mathrm{OH})_{2} ;$ (3) the diffusion of $\mathrm{Ca}^{2+} / \mathrm{Mg}^{2+}$ from the bulk solution to the $\mathrm{Na}^{+}$detached site of cancrinite; (4) the ion exchange between $\mathrm{Ca}^{2+} / \mathrm{Mg}^{2+}$ and $\mathrm{Na}^{+}$; (5) the diffusion of $\mathrm{Na}^{+}$to the bulk solution [28]. It can be speculated that the alkali recovery process with $\mathrm{CaO}$ as an addition may be controlled by the third step or the fifth step in this study based on a consideration of the hydration process, the obtained rate equation and the activation energy. In contrast, the process with $\mathrm{MgO}$ as an addition may be mostly controlled by the first step at low temperatures, and the rate equation together with the activation energy is consistent with the results of $\mathrm{MgO}$ hydration under similar conditions [27]. Therefore, as the $\mathrm{MgO}$ hydration rate increases with increasing temperature, the recovery ratio of $\mathrm{Na}_{2} \mathrm{O}$ with pure $\mathrm{MgO}$ as an addition also increases significantly.

As shown above, the alkali recovery process with $\mathrm{MgO}$ as an addition was controlled by internal diffusion, rather than by reaction at higher temperatures. Besides, for 30 minutes the extraction of alkali using $\mathrm{MgO}$ (Figure 7e) was much lower than when using $\mathrm{CaO}$ (as compared to Figure 7a), and it was because the hydration of $\mathrm{MgO}$ was relatively slow compared with $\mathrm{CaO}$, so there was an induction period when using $\mathrm{MgO}$. Moreover, as the solubility of calcium hydroxide is higher than that of magnesium hydroxide, the hydrolysis rate of magnesium hydroxide may be slower than that of calcium hydroxide. Theoretically, the cancrinite is hexagonal with the space group of $\mathrm{P}_{3}$ [23], and $\mathrm{Mg}^{2+}$ was easier to obtain through the openings as the radius of $\mathrm{Mg}^{2+}$ is smaller than that of $\mathrm{Ca}^{2+}$. However, the experimental results show that the recovery ratio does not increase monotonously with the increasing $\mathrm{MgO}$ proportion, as shown in Figure 4. It can be explained by the fact that the cancrinite transformed to hydrotalcite-like compounds bearing $\mathrm{Mg}$, of which the lamellar structure as well as the 
loosened surface was conducive to the further substitution of $\mathrm{Na}^{+}[13,30]$. However, the hydration of $\mathrm{MgO}$ was speculated to be much faster than the substitution reaction, together with the lesser usage of Me to exchange $\mathrm{Na}$ at high temperatures, leading to the increasing existence of $\mathrm{Mg}(\mathrm{OH})_{2}\left(\mathrm{Or} \mathrm{Ca}(\mathrm{OH})_{2}\right)$ on the surface of solid products upon further addition. This may in turn have prevented the diffusion of $\mathrm{Na}^{+}$from the cancrinite to the bulk solution. As a result, the recovery efficiency decreased rather than increased when the addition proportion of $\mathrm{MgO}$ was higher than $50 \%$.

\subsection{FTIR Spectra Analysis}

To explore the frameworks and the valence-bond structures, the FTIR spectra of the red mud and all leached solid samples were collected in the range of $4000-400 \mathrm{~cm}^{-1}$ at room temperature. The results are shown in Figure 8.

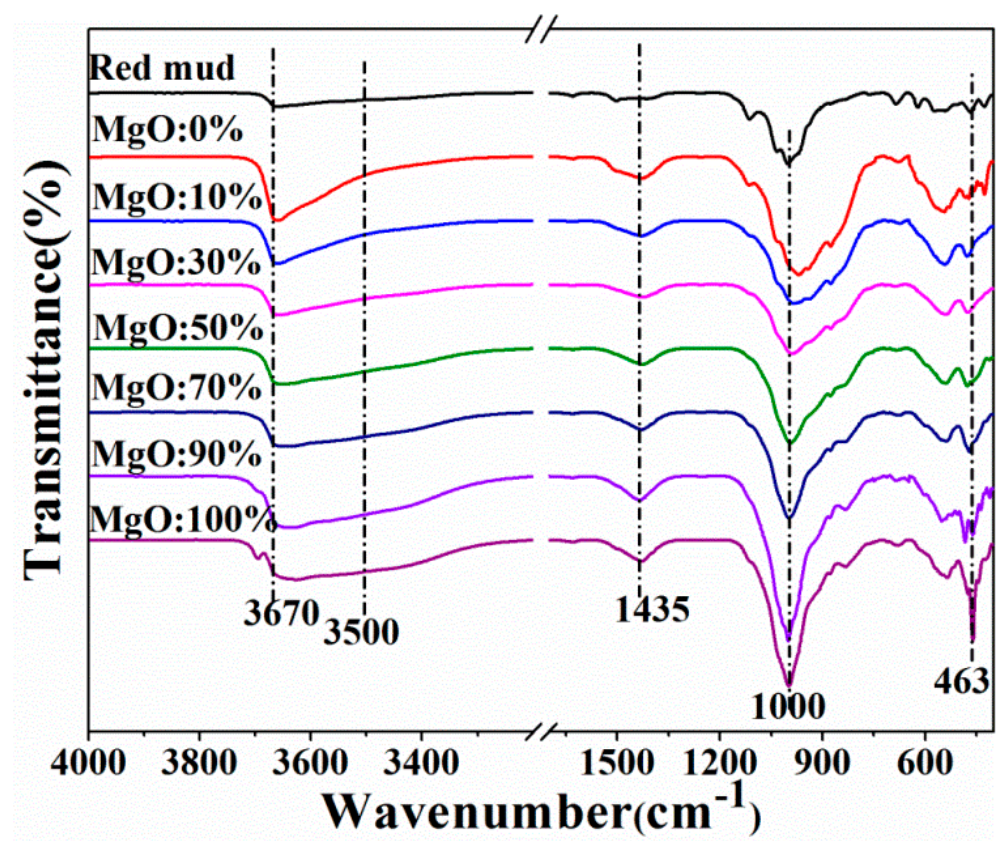

Figure 8. FTIR spectra of solid samples at $200^{\circ} \mathrm{C}$.

The peaks around $3700-3500 \mathrm{~cm}^{-1}$ can be attributed to the vibration of $\mathrm{CaO}-\mathrm{H}$ and $\mathrm{AlO}-\mathrm{H}$ bonds in the solids [31], and the peak intensity shows a sudden increase with the addition of $\mathrm{CaO}$, which is consistent with the phase changes. The broad absorption bands around $3500-3400 \mathrm{~cm}^{-1} \mathrm{can} \mathrm{be}^{-}$ attributed to the $-\mathrm{OH}$ stretching vibration of hydroxyl groups in layer structures [32]. Owing to the overlapping of $\mathrm{Mg}-\mathrm{OH}$ and $\mathrm{Al}-\mathrm{OH}$ bonds related with newly formed hydrotalcite-like structures, the bands in this region became stronger and broader with the increasing proportion of $\mathrm{MgO}$. The peaks between 1500 and $1400 \mathrm{~cm}^{-1}$ are attributed to the overtone of $\mathrm{Mg}-\mathrm{O}$ and $\mathrm{Al}-\mathrm{O}$ lattice vibrations [33]. The absorption bands around $1000 \mathrm{~cm}^{-1}$ are generally assigned to the metal-oxygen skeletal stretching and bending vibration of hydrotalcite, and the peaks around $463 \mathrm{~cm}^{-1}$ can be attributed to $\mathrm{Mg}-\mathrm{O}$ vibrations in the mixed $\mathrm{Mg}-\mathrm{Al}$ oxide. The increasing intensity of these two peaks shows strong evidence of the production of hydrotalcite-like structures [34,35]. To sum up, the formation of hydrotalcite-like structures is proved by the significant changes in FTIR spectra.

\subsection{Solid Morphology}

There are two types of appearance of solids after dealkalization at $200{ }^{\circ} \mathrm{C}$, as shown in Figure 9. The polyhedral particles with a dense structure are verified to be $\mathrm{Ca}_{2.93} \mathrm{Al}_{1.97} \mathrm{Si}_{0.64} \mathrm{O}_{2.56}(\mathrm{OH})_{9.44}$ by EDS analysis in Figure 9a', and the dense structure further supports the speculation that the reaction is controlled by internal diffusion with $\mathrm{CaO}$ as an addition. Moreover, a small amount of $\mathrm{Na}$ was 
still detected. However, the solid products containing Mg show a lamellar appearance with a loose structure. For example, 30\% MgO addition caused sporadical slakes distributed on the dense particles of calcium garnet, and more $\mathrm{MgO}$ addition led to the generation of more slakes and their aggregates. The lamellar and loose structures are consistent with the morphology of hydrotalcite-like structures which have been reported by other researchers [35].
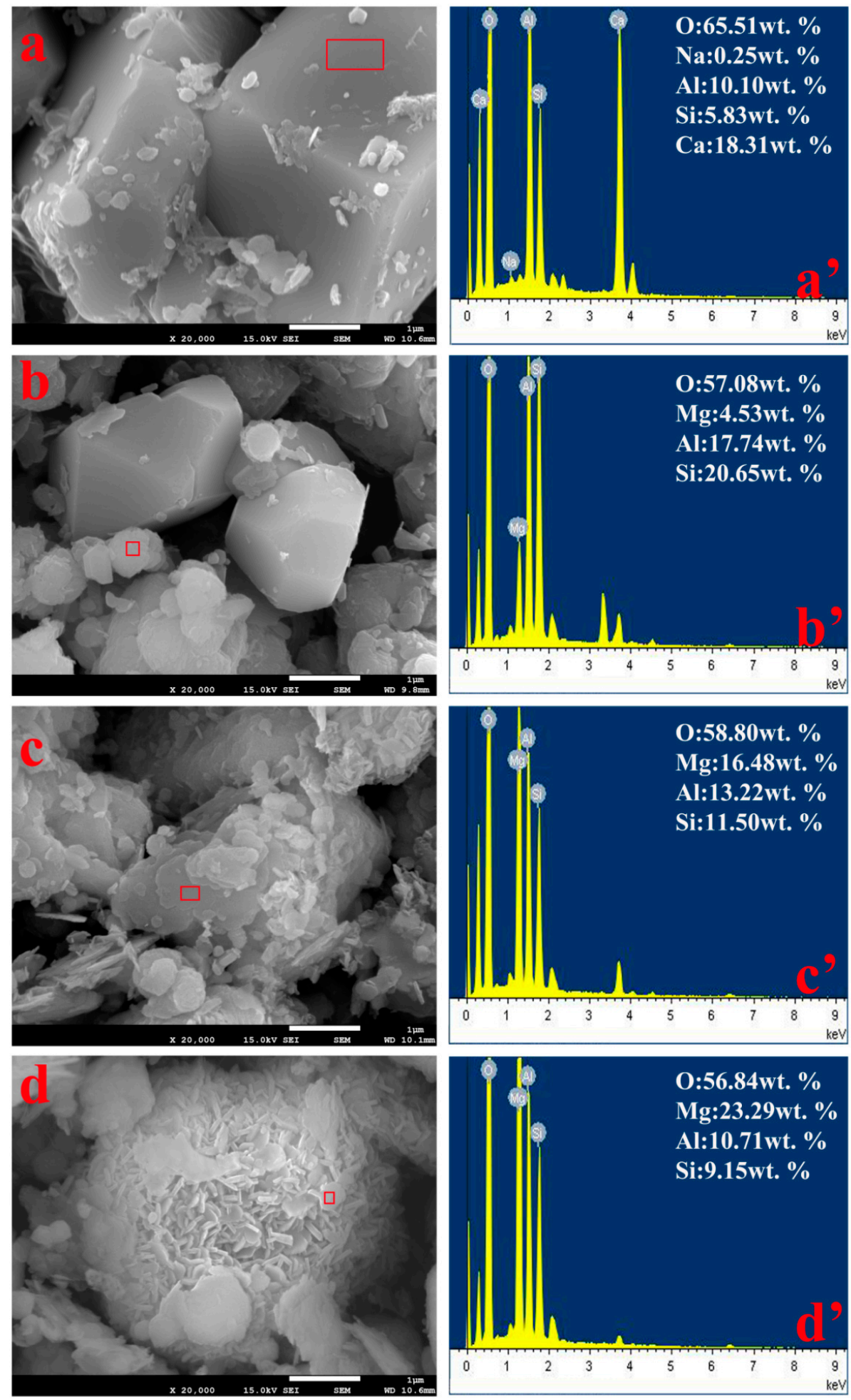

Figure 9. Morphologies of the solid products at $200{ }^{\circ} \mathrm{C}:\left(\mathbf{a}-\mathbf{a}^{\prime}\right) 0 \% \mathrm{MgO}$ addition; (b-b') $30 \% \mathrm{MgO}$ addition; (c-c') $70 \% \mathrm{MgO}$ addition and (d-d') $100 \% \mathrm{MgO}$ addition. 


\section{Conclusions}

Recovery of alkali from Bayer red mud was investigated systematically with $\mathrm{CaO}$ and/or $\mathrm{MgO}$ as additions for the first time. It was found that the blend of $\mathrm{CaO}$ and $\mathrm{MgO}$ had a better capacity to substitute alkali from the red mud when the temperature was no less than $200{ }^{\circ} \mathrm{C}$. The highest $\mathrm{Na}_{2} \mathrm{O}$ recovery of $89.3 \%$ with $\mathrm{N} / \mathrm{S}$ of 0.03 was obtained at $50 \% \mathrm{MgO}$ addition at $200{ }^{\circ} \mathrm{C}$. Moreover, $\mathrm{MgO}$ substitution to $\mathrm{Na}_{2} \mathrm{O}$ was found to be more temperature-dependent than that of $\mathrm{CaO}$ through different reaction mechanisms. The $\mathrm{Na}_{2} \mathrm{O}$ recovery process with $\mathrm{MgO}$ as an addition was controlled by reaction when the temperature was lower than $200^{\circ} \mathrm{C}$, but it was controlled by internal diffusion at a higher temperature. However, the process was always controlled by internal diffusion in the whole temperature range studied when $\mathrm{CaO}$ was used as an addition.

XRD analysis, FTIR analysis and SEM-EDS confirmed the hydrotalcite-like structure of solid products bearing $\mathrm{Mg}$. To sum up, the recovery efficiency was the result of the reaction kinetics and the characteristics of solid products. This study can provide reference for the reaction mechanism investigation of alkali recovery from red mud based on ion exchange. It also provides a new idea for the treatment of red mud.

Supplementary Materials: The following are available online at http://www.mdpi.com/2075-163X/9/5/269/s1, Figure S1: Kinetic fitting of (a) the plots of $\left[1-(1-\alpha)^{1 / 3}\right]$ versus time for $\mathrm{CaO},(\mathrm{b}) \ln \left(K_{\mathrm{a}}\right)$ versus temperature for $\mathrm{CaO}$, (c) the plots of $\left[1-\frac{2}{3} \alpha-(1-\alpha)^{2 / 3}\right]$ versus time for $\mathrm{MgO}$ lower than $200^{\circ} \mathrm{C},(\mathrm{d}) \ln \left(K_{\mathrm{a}}\right)$ versus temperature for $\mathrm{MgO}$ lower than $200{ }^{\circ} \mathrm{C}$, (e) the plots of $\left[1-(1-\alpha)^{1 / 3}\right]$ versus time for $\mathrm{MgO}$ higher than $200{ }^{\circ} \mathrm{C}$ and (f) $\ln (\mathrm{Ka})$ versus temperature for $\mathrm{MgO}$ higher than $200^{\circ} \mathrm{C}$, Table S1: Recovery ratio (wt. \%) of alkali extraction on time with pure $\mathrm{CaO}$ as addition under different temperatures, Table S2: Recovery ratio (wt. \%) of alkali extraction on time with pure $\mathrm{MgO}$ as addition under different temperatures.

Author Contributions: Investigation, B.Z. and S.C.; Supervision, F.C.; Writing-original draft, B.Z.; Writing-review \& editing, B.Z., S.C., F.C., F.Z. and Y.Z.

Funding: This research was funded by the National Natural Science Foundation of China (No. 51674233); the Henan Transfer Project of CAS Scientific and Technological Achievements (No. 2019103); the Guangxi Natural Science Foundation (No. 2016GXNSFEA380002); and the Shanxi Province Coal Based Low-carbon Technology Major Projects (No. MC2016-05).

Conflicts of Interest: The authors declare no conflict of interest.

\section{References}

1. Chen, H.; Huo, Y.B.; Yuan, Y.; Shen, L.Y.; Xia, Y.Z.; Chai, Y.; Zhang, Q.; Wang, N.N. Regional statistics of alumina production in China from January to December 2017. China Alum. Mon. 2018, 230, 130-131.

2. Roosen, J.; Van Roosendael, S.; Borra, C.R.; Van Gerven, T.; Mullens, S.; Binnemans, K. Recovery of scandium from leachates of Greek bauxite residue by adsorption on functionalized chitosan-silica hybrid materials. Green Chem. 2016, 18, 2005-2013. [CrossRef]

3. Lehoux, A.P.; Lockwood, C.L.; Mayes, W.M.; Stewart, D.I.; Mortimer, R.J.G.; Gruiz, K.; Burke, I.T. Gypsum addition to soils contaminated by red mud: Implications for aluminium, arsenic, molybdenum and vanadium solubility. Environ. Geochem. Health 2013, 35, 643-656. [CrossRef] [PubMed]

4. Smith, P. The processing of high silica bauxites-review of existing and potential processes. Hydrometallurgy 2009, 98, 162-176. [CrossRef]

5. Shoppert, A.A.; Loginova, I.V.; Rogozhnikov, D.A.; Karimov, K.A.; Chaikin, L.I. Increased as adsorption on maghemite-containing red mud prepared by the alkali fusion-leaching method. Minerals 2019, 9, 60. [CrossRef]

6. Power, G.; Grafe, M.; Klauber, C. Bauxite residue issues: I. Current management, disposal and storage practices. Hydrometallurgy 2011, 108, 33-45. [CrossRef]

7. Klauber, C.; Gräfe, M.; Power, G. Bauxite residue issues: II. Options for residue utilization. Hydrometallurgy 2011, 108, 11-32. [CrossRef]

8. Liu, Z.B.; Li, H.X. Metallurgical process for valuable elements recovery from red mud-A review. Hydrometallurgy 2015, 155, 29-43. [CrossRef] 
9. Enserink, M. Envrionment after red mud flood, scientists try to halt wave of fear and rumors. Science 2010, 330, 432-433. [CrossRef] [PubMed]

10. Ning, G.; Zhang, B.; Liu, C.; Li, S.; Ye, Y.; Jiang, M. Large-scale consumption and zero-waste recycling method of red mud in steel making process. Minerals 2018, 8, 102. [CrossRef]

11. Brunori, C.; Cremisini, C.; Massanisso, P.; Pinto, V.; Torricelli, L. Reuse of a treated red mud bauxite waste: Studies on environmental compatibility. J. Hazard. Mater. 2005, 117, 55-63. [CrossRef] [PubMed]

12. Grafe, M.; Power, G.; Klauber, C. Bauxite residue issues: III. Alkalinity and associated chemistry. Hydrometallurgy 2011, 108, 60-79. [CrossRef]

13. Hanahan, C.; McConchie, D.; Pohl, J.; Creelman, R.; Clark, M.; Stocksiek, C. Chemistry of seawater neutralization of bauxite refinery residues (red mud). Environ. Eng. Sci. 2004, 21, 125-138. [CrossRef]

14. Rai, S.; Wasewar, K.L.; Agnihotri, A. Treatment of alumina refinery waste (red mud) through neutralization techniques: A review. Waste Manage. Res. 2017, 35, 563-580. [CrossRef]

15. Qu, Y.; Li, H.; Wang, X.; Tian, W.; Shi, B.; Yao, M.; Zhang, Y. Bioleaching of major, rare earth, and radioactive elements from red mud by using indigenous chemoheterotrophic bacterium acetobacter sp. Minerals 2019, 9, 67. [CrossRef]

16. Johnston, M.; Clark, M.W.; McMahon, P.; Ward, N. Alkalinity conversion of bauxite refinery residues by neutralization. J. Hazard. Mater. 2010, 182, 710-715. [CrossRef] [PubMed]

17. Rai, S.; Wasewar, K.L.; Lataye, D.H.; Mukhopadhyay, J.; Yoo, C.K. Feasibility of red mud neutralization with seawater using Taguchi's methodology. Int. J. Environ. Sci. Technol. 2013, 10, 305-314. [CrossRef]

18. Li, R.B.; Zhang, T.G.; Liu, Y.; Lv, G.Z.; Xie, L.Q. Calcification-carbonation method for red mud processing. J. Hazard. Mater. 2016, 316, 94-101. [CrossRef] [PubMed]

19. Zhang, Y.; Zheng, S.L.; Wang, X.H.; Du, H.; Fang, Z.Z.; Zhang, Y. Reactive extraction of sodium hydroxide from alkali solutions for the separation of sodium and aluminum - part I. effect of extractant. Hydrometallurgy 2015, 154, 47-55. [CrossRef]

20. Zhong, L.; Zhang, Y.F.; Zhang, Y. Extraction of alumina and sodium oxide from red mud by a mild hydro-chemical process. J. Hazard. Mater. 2009, 172, 1629-1634. [CrossRef]

21. Luo, Z.T.; Xiao, Y.L.; Zhang, L.; Wang, X.; Zheng, Y.R.; Yang, J.J. Multi-stage cycle dealkalization and alkali recovery process of red mud slurry. J. Univ. Jinan Sci. Technol. 2013, 27, 369-372.

22. Yang, J.J.; Li, J.W.; Xiao, Y.L.; Luo, Z.T.; Han, Y.F. Research on dealkalization of sintering process red mud by lime process at normal atmosphere and mechanism thereof. Inorg. Chem. Ind. 2012, 44, 40-42.

23. Li, R.B.; Li, X.L.; Wang, D.X.; Liu, Y.; Zhang, T.A. Calcification reaction of red mud slurry with lime. Powder Technol. 2018, 333, 277-285. [CrossRef]

24. Venancio, L.C.A.; Souza, J.A.S.; Macedo, E.N.; Botelho, F.A.; de Oliveira, A.M.; Fonseca, R.S. Bauxite residue amendment through the addition of $\mathrm{Ca}$ and or $\mathrm{Mg}$ followed by carbonation. In Light Metals; Ratvik, A.P., Ed.; Springer International Publishing Ag: Phoenix, AZ, USA, 2017; pp. 53-59.

25. Zheng, X.F.; Hu, J.; Jiang, M.; Xue, Z.X. Study on optimization of dealkalization process on adding lime to red mud produced by low temperature Bayer process. Light Metals 2010, 4, 21-23.

26. Amaral, L.F.; Oliveira, I.R.; Salomao, R.; Frollini, E.; Pandolfelli, V.C. Temperature and common-ion effect on magnesium oxide (MgO) hydration. Ceram. Int. 2010, 36, 1047-1054. [CrossRef]

27. Maryska, M.; Blaha, J. Hydration kinetics of magnesium oxide-Part 3. Hydration rate of $\mathrm{MgO}$ in terms of temperature and time of its firing. Ceram. Silikaty 1997, 41, 121-123.

28. Li, X.F.; Ye, Y.Z.; Xue, S.G.; Jiang, J.; Wu, C.; Kong, X.F.; Hartley, W.; Li, Y.W. Leaching optimization and dissolution behavior of alkaline anions in bauxite residue. Trans. Nonferrous Met. Soc. China 2018, 28, 1248-1255. [CrossRef]

29. Safari, V.; Arzpeyma, G.; Rashchi, F.; Mostoufi, N. A shrinking particle-shrinking core model for leaching of a zinc ore containing silica. Int. J. Miner. Process. 2009, 93, 79-83. [CrossRef]

30. Couperthwaite, S.J.; Johnstone, D.W.; Millar, G.J.; Frost, R.L. Neutralization of acid sulfate solutions using bauxite refinery residues and its derivatives. Ind. Eng. Chem. Res. 2013, 52, 1388-1395. [CrossRef]

31. Qu, J.; Zhong, L.H.; Li, Z.; Chen, M.; Zhang, Q.W.; Liu, X.Z. Effect of anion addition on the syntheses of Ca-Al layered double hydroxide via a two-step mechanochemical process. Appl. Clay Sci. 2016, 124, 267-270. [CrossRef]

32. Heraldy, E.; Nugrahaningtyas, K.D.; Sanjaya, F.B.; Darojat, A.A.; Handayani, D.S.; Hidayat, Y. In effect of reaction time and (Ca plus $\mathrm{Mg}$ )/Al molar ratios on crystallinity of Ca-Mg-Al layered double hydroxide. In Proceedings of the 10th Joint Conference on Chemistry, Solo, Indonesia, 8-9 September 2015. 
33. Del Arco, M.; Martin, C.; Martin, I.; Rives, V.; Trujillano, R. A FTIR spectroscopic study of surface acidity and basicity of mixed $\mathrm{Mg}$, Al-oxides obtained by thermal decomposition of hydrotalcite. Spectrochim. Acta Part A Mol. Spectrosc. 1993, 49, 1575-1582. [CrossRef]

34. Kuśtrowski, P.; Sułkowska, D.; Chmielarz, L.; Rafalska-Łasocha, A.; Dudek, B.; Dziembaj, R. Influence of thermal treatment conditions on the activity of hydrotalcite-derived $\mathrm{Mg}-\mathrm{Al}$ oxides in the aldol condensation of acetone. Micropor. Mesopor. Mat. 2005, 78, 11-22. [CrossRef]

35. Olszówka, J.E.; Karcz, R.; Bielańska, E.; Kryściak-Czerwenka, J.; Napruszewska, B.D.; Sulikowski, B.; Socha, R.P.; Gawel, A.; Bahranowski, K.; Olejniczak, Z.; et al. New insight into the preferred valency of interlayer anions in hydrotalcite-like compounds: The effect of Mg/Al ratio. Appl. Clay Sci. 2018, 155, 84-94. [CrossRef]

(C) 2019 by the authors. Licensee MDPI, Basel, Switzerland. This article is an open access article distributed under the terms and conditions of the Creative Commons Attribution (CC BY) license (http://creativecommons.org/licenses/by/4.0/). 